\title{
PREVALENCE OF OBESITY AND HIGH LEVEL OF CHOLESTEROL IN HYPERTENSION: Analysis of Data from the University College Hospital, Ibadan
}

\author{
YEKEEN L.A, SANUSI R.A AND KETIKU A.O* \\ Department of Human Nutrition, College of Medicine University of Ibadan, Ibadan.
}

\begin{abstract}
This study was undertaken to determine what proportion of patients with hypertension are obese and or have elevated serum cholesterol. The data of two hundred and fifty patients who attended the outpatient clinics of the University College Hospital, Ibadan from January 1998 to December 2001 were analysed. Almost half of the subjects (48.8\%) had mild, $40.8 \%$ moderate, and $8.8 \%$ severe hypertension. While mild hypertension was more in the females (55.4\%), moderate and severe hypertension was more among males. Among the subjects that were overweight $(B M I>25<30), 44 \%$ were males and $56 \%$ were females. There were more obese (BMI>30) among the females (63.6\%) than the males (36.4\%). Only 166 of the subjects had serum cholesterol analysis, and only $9.6 \%$ had a hyper-cholesterol (>240mg/dl) level. Obesity and hyper-cholesterol and hypertension are known risk factors in cardiovascular diseases. Since weight reduction has been noted to reduce severity of hypertension, this should be a cost effective intervention in both the control of hypertension and lowering the risk of coronary heart diseases.
\end{abstract}

Keywords: hypertension, obesity, serum cholesterol. Running title: prevalence of obesity in hypertension.

${ }^{*}$ Author for correspondence

\section{INTRODUCTION}

Obesity and high blood cholesterol have been identified as risk factors in hypertension (Jones and Davis 1992). People with hypertension are also more likely to have lipid abnormality and obesity than those with normal blood pressure (Wannarinthee et al 1998). Furthermore blood pressure is strongly related to body weight and control of obesity is a critical component of prevention and control of hypertension (Kummayinka 1997). Clinical trials have also suggested a reduction in the incidence of coronary heart disease by lowering serum cholesterol levels.

Although the population prevalence of obesity and hypertension is not known, a country-wide survey in Nigeria in 1990-91 put the prevalence of hypertension at $11.2 \%$ in those older than I5years old (Mabadeje, 1999). Hypertension is the most important of the known risk factors of cardiovascular disease (Sokolow, Mcllroy and Roberts 1975).

Since each of these conditions is associated with appreciable morbidity and mortality, and they may occur together increasing the associated complications, this study was undertaken to determine the percentage (or proportion) of patients with hypertension that are obese or have hypercholesterolemia or both. As dietary control and exercise can influence obesity and high cholesterol level, these may become more prominent in the management of hypertension. This is because epidemiologic studies have suggested that $70 \%$ of elevated blood pressure is due to environmental factors, prominent among which is weight gain (Pickering, 1968).

The general objective of this study was to determine the proportion of patients with hypertension who are obese and who also have high blood levels of cholesterol.

\section{METHODOLOGY}

This study was descriptive, cross-sectional and retrospective in design. The location of the study was the medical outpatients (MOP) clinic of the University College Hospital (UCH), lbadan, Nigeria. This is the oldest teaching Hospital in Nigeria with an outpatient population of over 200,000 per year (Ajayi, 1997).

Subjects of the study were hypertensive patients who were attending MOP clinic for medical treatment. The selection criterion was open and it included all hypertensive patients that had attended that clinic between January 1998 and December 2001. The sampling technique adopted was purposive. Incomplete 
data in the patient's records was the exclusion criterion. Two hundred and fifty (250) patients who received treatment from January 1998 to January 2001 and had adequate records, constituted the study sample.

Data was extracted from individual case notes, which were retrieved from the medical records department after all issues of ethical clearance had been adequately satisfied. Extracted data included; age, gender, weight, height, blood pressure on the first visit and total cholesterol in blood. Body mass index (BM1) was derived from weight and height measurements. Data analysis was performed using the statistical package for social sciences (SPSS) for window version 7.5. Main analysis included descriptive statistics; however relationships were explored using crosstabulations, correlation and linear regression.

\section{RESULTS}

A total of two hundred and fifty subjects were studied; One hundred and two (40.8\%) were males, while one hundred and forty eight $(59.2 \%)$ were females. The mean age was 48 $( \pm 9.1)$ yrs. and mean BMI $28.6( \pm 4.1)$ as shown in Table 1. The profile of severity of hypertension and gender (Table 2) showed the prevalence of mild hypertension to be higher in females while moderate and severe hypertension were more in males.

Table 1: Characteristics of Subjects and Gender

\begin{tabular}{|l|l|l|l|l|l|l|}
\hline & \multicolumn{3}{|c|}{ MALES } & \multicolumn{3}{c|}{ FEMALES } \\
\hline & $\mathrm{N}$ & Mean & SD & $\mathrm{N}$ & Mean & SD \\
\hline Age $(\mathrm{yrs})$ & 102 & 48.2 & 9.1 & 148 & 47.6 & 9.1 \\
\hline BMI $\left(\mathrm{kg} / \mathrm{m}^{2}\right)$ & 102 & 27.9 & 3.2 & 148 & 29.1 & 4.6 \\
\hline Cholesterol $(\mathrm{mg} / \mathrm{dl})$ & 77 & 209.8 & 44.4 & 89 & 208.6 & 29.2 \\
\hline Diastolic BP $(\mathrm{mmHg})$ & 102 & 108.5 & 13.5 & 148 & 105.5 & 12.8 \\
\hline Systolic BP $(\mathrm{mmHg})$ & 102 & 173.5 & 19.7 & 148 & 171.5 & 17.5 \\
\hline
\end{tabular}

Table 2: Gender, Obesity and Hypertension

\begin{tabular}{|l|l|l|l|l|}
\hline & \multicolumn{2}{|c|}{ MALES } & \multicolumn{2}{c|}{} \\
\hline Hypertension & $\mathrm{n}$ & $\%$ & $\mathrm{n}$ & $\%$ \\
\hline Mild DBP>90mmHg & 40 & 39.2 & 82 & 55.4 \\
\hline Moderate DBP>105mmHg & 47 & 46.0 & 55 & 37.2 \\
\hline Severe DBP> 130mmHg & 12 & 11.8 & 10 & 6.7 \\
\hline Obesity & $\mathrm{n}$ & $\%$ & $\mathrm{n}$ & $\%$ \\
\hline Overweight (BMI 25-29.9) & 60 & 58.8 & 76 & 51.4 \\
\hline Grade 2 obese (BMI 3 0-39.9) & 28 & 27.5 & 49 & 33.1 \\
\hline Grade 3 Obese (BMI >40) & 0 & 0.0 & 5 & 3.4 \\
\hline Non-Obese (BMl 18.5-24.99) & 12 & 11.8 & 16 & 10.8 \\
\hline
\end{tabular}

This difference is statistically significant at $\mathrm{p}<0.05$. Among the males $40(39.2 \%)$ had mild hypertension, while $47(46 \%)$ had "moderate" hypertension and 12 (11.4\%) had "severe" hypertension. Among the females, while 82 $(55.4 \%)$ had mild hypertension, $55(37.2 \%)$ had moderate hypertension and 10 (6.7\%) had severe hypertension. This result suggests that except in the mild hypertension category, there are more males in the moderate and severe categories of hypertension.

There are also more who are overweight (BMl>25<30) among the males $(59 \%)$ than in females $(51 \%)$. However grade 2 obesity $(\mathrm{BMl}>30<40)$ is more in females $(33 \%)$ than in males $(28 \%)$. The non-obese are about equal among the males (11.8\%) and females $(10.8 \%)$. Only 166 of the subjects bad serum cholesterol estimation and among these 26 $(34 \%)$ males and $27(30 \%)$ females had a "desirable" level of less than $200 \mathrm{mg} / \mathrm{dl}$ (National Cholesterol Education Program, 1988). In the "borderline" (serum cholesterol level of $>200<240 \mathrm{mg} / \mathrm{dl})$ category, $42(43 \%)$ were males while $55(57 \%)$ were females. Among the 16 that had high level of serum cholesterol (hyper-cholesterol), 9 (5 6\%) were males while 7 (44\%) were females. The proportion of patients having hyper-cholesterol in the study is low (9.6\%). These are shown in Table 3.

A brief summary of the interface between obesity and hypertension shows that majority $(50 \%)$ of those with mild and moderate hypertension are in the overweight category (BMI > $25<30$ ). Also greater proportion of females in grade one $(\mathrm{BMI}>25<30)$ and two (BMI > $30<40$ ) obesity, had "mild" hypertension while greater proportion of males 
in similar categories of obesity had "moderate" hypertension (Table 4).

Table 3: Cholesterol profile of Obese Hypertensives

\begin{tabular}{|l|l|l|l|l|}
\hline \multirow{2}{*}{$\begin{array}{l}\text { Serum } \\
\text { Cholesterol }\end{array}$} & \multicolumn{2}{|c|}{ MALE } & \multicolumn{2}{c|}{ FEMALE } \\
\cline { 2 - 5 } & $\mathrm{n}$ & $\%$ & $\mathrm{n}$ & $\%$ \\
\hline Desirable & 26 & 33.8 & 27 & 30.3 \\
\hline Borderline & 42 & 54.5 & 55 & 61.8 \\
\hline High & 9 & 11.7 & 7 & 7.8 \\
\hline Total & 77 & 100 & 89 & 100 \\
\hline
\end{tabular}

Desirable $=<200 \mathrm{mg} / \mathrm{di}$

Borderline $=>200<240 \mathrm{mg} / \mathrm{di}$

High $>240 \mathrm{mg} / \mathrm{di}$

(National Cholesterol Education Programme 1998)

\section{DISCUSSION}

The population specific prevalence of hypertension in Nigeria is not known with certainty. However in a countrywide survey in 1990-1991 Mabadeje (1999) reported a rate of $11.2 \%$ in those aged 15 years old and above. Olatunbosun et al (2000) in a study of urbanbased civil servants in Ibadan found the prevalence of hypertension to be $10.3 \%$, although this was higher in men $(13.9 \%)$ than in women $(5.3 \%)$. Similarly, the prevalence of hypertension in the elderly whose ages were over 55years was 30\% (Ezenwaka et al 1997). Okesina et al (1999) also observed a prevalence of $15.2 \%$ hypertension in Maiduguri with a rate of $19.1 \%$ in males and $10.3 \%$ in females. The degree of hypertension varies among the sexes. This study shows that while there was more of the mild hypertension in the females $(55.4 \%)$, more of the moderate and severe categories occur in men. Lack of categorization of the degree of hypertension limits easy comparison with previous studies. Cooper et al (1997) had reported a hypertension prevalence of $16 \%$ in West Africa and had implicated obesity and dietary intake of sodium and potassium.

While overweight category was higher in males $(58.5 \%)$ than in females $(51.3 \%)$, grade two obesity was more in the females $(33 \%)$ than males $(27 \%)$. These differences were statistically significant $(p<0.05)$ and are consistent with the findings of previous studies (Olatunbosun et al 2000, Okesina et al 1999). Okesina et al (1999) had reported an overall prevalence of obesity to be $2 \%$ in the Maiduguri study with a higher $3.2 \%$ in females and $1.2 \%$ in males.

The percentage of subjects whose BMI was $>30$ in this study was $33 \%$ in females and $27.4 \%$ in males. Okosun et al (1999) had suggested that the prevalence of hypertension was closely linked to abdominal adiposity; however since waist-hip ratio was not measured in this study, it is difficult to confirm their observation with the findings of the present study. Ezenwaka et al (1997) had also reported a higher prevalence of obesity and high blood pressure in women and in urban settings. Hyper-cholesterol was found in $5.4 \%$ of the men and $4.2 \%$ of the females in this study.

Table 4: Hypertension severity and Obesity category

\begin{tabular}{|l|l|l|l|l|l|l|}
\hline \multicolumn{7}{|c|}{ MYPERTENSION CATEGORY } \\
\hline $\begin{array}{l}\text { Obesity } \\
\text { Category }\end{array}$ & Mild (\%) & Moderate (\%) & Severe(\%) & Mild (\%) & Moderate(\%) & Severe(\%) \\
\hline $\begin{array}{l}\text { Overweight } \\
(\text { BMI 25-29.9) }\end{array}$ & $23(22.5)$ & $29(28.4)$ & $6(5.9)$ & $45(30.4)$ & $29(19.6)$ & $2(1.4)$ \\
\hline $\begin{array}{l}\text { Obese } \\
(\mathrm{BMI}>30)\end{array}$ & $09(8.8)$ & $14(13.7)$ & $5(4.9)$ & $28(18.9)$ & $19(12.8)$ & $07(4.7)$ \\
\hline & 32 & 43 & 11 & 73 & 48 & 09 \\
\hline
\end{tabular}

Okesina et al (1999), had found a zero \% when hyper-cholesterol was defined as a level greater than $206.7 \mathrm{mgldl}$, however the criterion for this study is serum cholesterol level greater than 240mg/dl (National Cholesterol Education Programme 1998). As the prevalence of hypertension in several population studies has overshot the $10 \%$ trigger- point, it is necessary to activate intervention to lower this rate. The control of dietary energy intake, sodium consumption and inactivity are areas of potential interventions. So far the prevalence of coronary heart disease is still low in Africa; paradoxically the risk factors of hypertension, obesity and high serum cholesterol associated with coronary heart disease are emerging.

As exploration of effect of obesity categories on severity of hypertension showed that while prevalence of obesity (BMl> 30$)$ is almost twice as high in females than in males, prevalence of moderate hypertension is higher in males than in females. It is safe therefore to suggest that except in severe hypertension, obesity and hypertension are highly associated. 
The importance of this finding is to enable "care-givers" in hypertension pay more attention to the control of obesity so that several complications associated with it might be prevented. The risk factors of coronary heart disease (CHD) already seen in several of the obese patients can be lowered by dietary intervention, as well as other medical control of hypertension. It is clear that the population prevalence of obesity, hypertension and hypercholesterol if known will be useful in planning interventions.

\section{REFERENCES}

Ajayi, OO (1997). The University College Hospital, Ibadan. Preface of the Chief Medical Director to the 1997 Diary. Wemilore Press (Nig) Limited.

Ezenwaka CE, Akanji A0, Akanji BO, Unwin NC, Adejuwon CA (1997). The prevalence of insulin resistance and other cardiovascular disease risk factors in healthy elderly south western Nigerians. Artherosclerosis 128(2) 201-211.

Jones $J$ and Davis KA (1992). Risk factors for coronary disease in a black population. J. Am. Medical Association 84:393-398.

Kummayinka SK (1997). The impact of obesity on hypertension management in African American. J. Healthcare for the poor and underserved(3) 352-5

Mabadeje AF (1999). WHO-ISH Guidelines for the management of hypertension complications in
Africa: The Nigerian experience. Clin. Exptl. Hypertension; 21 (5-6) 671-681.

National Cholesterol Education Program (1988). Report of the Expert Panel on Detection, Evaluation and Treatment of High blood Cholesterol in Adults. Arch. int. Med 148:36

Okesina AB, Oparinde DB, Akindoyin KA, Erasmus BT (1999). Prevalence of some risk factors of coronary heart disease in a rural Nigerian population. East Afr. J. Med. J. 76(4) 212-216.

Okosun IS, Forrester TE, Rotimi CN, Osotimehin BO, Muna WF, Cooper RS(1999). Abdominal adiposity in six populations of west African descents: prevalence and population attributable fraction of hypertension. Obesity Research; 7(5) 453-462.

Olatunbosun ST, Kaufman JS, Cooper RS, Bella AF (2000). Hypertension in a black population: prevalence and biosocial determinants of high blood pressure in a group of urban Nigerians. J. Human Hypertension 14(4) 249-25 7.

Sokolow M (1979). Clinical cardiology 3rd ed. Lange Medical. Pp 231-260 Los Altos, California.

Wannarinthee SC, Shaper AG, Durington PN, Perry (1998). Metabolic Syndrome. J. Human Hypertension 12 (ii) 1059-64.

Received: January 2003

Accepted in final form: June 2003 